Volume 11, Issue 12, December 2020, pp 1170-1174, Article ID: IJM_11_12_108

Available online at http://iaeme.com/Home/issue/IJM?Volume $=11 \&$ Issue $=12$

Journal Impact Factor (2020): 10.1471 (Calculated by GISI) www.jifactor.com

ISSN Print: 0976-6502 and ISSN Online: 0976-6510

DOI: 10.34218/IJM.11.12.2020.108

(C) IAEME Publication ${ }^{\text {scopus }}$ Scopus Indexed

\title{
TOURISM IN CHENNAI- A SPECIAL REFERENCE TO HERITAGE TOURISM
}

\author{
K.Vijayalakshmi \\ Ph.D. (Full-Time) Research Scholar, Department of Tourism and Hospitality Management \\ Bharath Institute of Higher Education and Research (BIHER), Selaiyur, Chennai
}

\section{Dr. T. Milton}

Research Supervisor and Dean Department of Tourism and Hospitality Management, Bharath Institute of Higher Education and Research (BIHER), Selaiyur, Chennai

\begin{abstract}
The growing worth of heritage in their reworking out the past history and dissemination of the identities, intensifies the heritage tourism in India. This study showcase the way of heritage is seen in the aspect of tourism in Chennai, Tamil Nadu. Hence the heritage reveals the nostalgic experience of the history through architecture and it influence the wealth and the style been practiced in the past by the rulers.
\end{abstract}

Keywords: Heritage, Tourism, Domestic tourist, Destinations, Architecture.

Cite this Article: K.Vijayalakshmi and Dr. T. Milton, Tourism in Chennai- a Special Reference to Heritage Tourism, International Journal of Management 11(12), 2020, pp 1170-1174.

http://iaeme.com/Home/issue/IJM?Volume=11\&Issue=12

\section{INTRODUCTION}

Tourism is a essential part of every beings life style in these busy world. Tourism is travel made for a recreational activity, leisure or business purpose.

The United Nation World Tourism Organization defines "Tourism is a social, cultural and economic phenomenon which entails the movement of people to countries or places outside their usual environment for personal or business/professional purposes".

\section{DEFINITION OF TOURISM}

Swiss professors Hunziker and Kraft (1942), describe the concept of tourism as "it is the sum of phenomena and relationship arising from the travel and stay of non-residents, as they should not have an accommodation as permanent and not having the idea of earning".

In 1963, the Rome Conference on Tourism defined only international tourists as:

"Travellers staying at least 24 hours in the country visited and the needs can be classified as follows:

- For leisure (recreation, holiday, health, study, religion, sport); 
- For business, family, mission, meeting; "

In 1978, UNWTO defined tourists as: “...tourist who spent one night in country or visitors who had a layover in transit time and used the accommodation amenities in the visited country".

\section{CONCEPT OF HERITAGE}

\subsection{THE HISTORY OF DEVELOPMENT IN HERITAGE TOURISM}

Cultural Tourism in its earliest form can be traced to the period of Romans. Mostly the rich undertook travel to enjoy and understand, different cultures. They considered such tours as a part of education of the royal people. In the middle age, in Europe, religious heritage, in the form of pilgrimage sites, was the main motivation for travel. By the beginning of the 18th century, the "Grand Tour" became an established activity for the sons of the aristocracy and gentry. It was mainly a tour to the places of artistic importance, especially in Europe. The end of the 19th century saw the beginning of the packaged heritage tourism, with Thomas Cook's arrangement of the first holiday trip to see the ancient historical monument of Egypt.

The development of heritage tourism has started its way to pick up speed and more and more locations were established. Accessibility became better with the development of road transport, especially the emergence of cars. The development of airways and sea transport made it possible for people to take up overseas travel to enjoy and understand the cultural heritage of other countries.

A governing body named UNESCO World Heritage site is composed of 21 state parties which elects by general assembly for a term of four year.

\subsection{DEFINTION AND MEANING}

Heritage means "something fetched from one peer group to other". The word Heritage describes the both natural and cultural facets. In the natural context, the heritage part includes such as the landscape, mountain, river, islands, flora and fauna. In the cultural context historical remains are buildings, architecture, traditions etc.

\subsection{CHENNAI AND ITS HERITAGE}

The cultural heritage state, Tamil Nadu, has its own historical significance, situated at the southern part of India, chennai formerly known as madras is the capital city of Tamil Nadu. It's about 350 years old but, still growing and pulsating with new emerging trends and activities.

Chennai encompass a great influence with rich tradition, modern amenities an technologies, historical and pilgrim centre's etc. Chennai is also enriched with the amenities of tourism like both the man-made amenities and the natural amenities.

\section{REVIEW OF LITERATURE:}

Light et al (1994) described Heritage Tourism as belonging to the middle-class, well -educated, middle -aged, no children, on holiday away from home and who have a prior knowledge of history. This view is largely supported by Balcar and Pearce (1996) and Prentice (1993).

Heritage is part of the cultural and tourism industries which represent the fastest growing sectors of the world's economy, second only to developments in Multimedia (Boylan, 1995).

"History is what a historian regards as worth recording and heritage is what contemporary society chooses to inherit and to pass on." (Turnbridge and Asworth 1996).

According to WTO (2000), culture and tourism have a symbiotic connection. Arts, crafts, dances, rituals and legends that are at risk of being forgotten by the younger generation may be revitalized when tourists show a keen interest in them. 


\section{OBJECTIVES OF THE STUDY}

- To create awareness on the tourist on the history and heritage in and around Chennai

- To offer the popular tourist spots in chennai which exist with the heritage potential.

- To showcase the tourist amenities in chennai.

- To identify the architectural heritage sites in chennai.

\section{HERITAGE TOURISM}

Heritage tourism is new phenomenon added to cultural tourism, but its origin was with the past ancient time of human existence. The features heritage sites are most important aspect to directly influence tourist to make their visit to places.

The Heritage tourism destinations vary with each significant characteristics with their natural environment and events for marketing purposes and the environmental activities been carried out to promote destinations. In India, the heritage building, generally represents the ancient history and the culture of nation.

\section{SIGNIFICANCE OF HERITAGE TOURISM}

Heritage tourism is rapidly growing in niche market. Tourist prefer heritage tourism because they can experience the local customs, arts, history, sites, and culture that significantly represents the distinct places. Heritage is considered as the cultural, economic, and political resources. It also a privilege of a country to expose the cultural wealth or also for creating a national image. As an economic source the heritage tourism plays a major role, as it will be in aspects of collecting artifacts, preserving, and presenting, also will have a sort of economic value in future and present too.

\section{METHODOLOGY}

The domestic tourist are chosen by adopting the connivance sampling method. Data's received from 225 inbound tourist with the help of questionnaire. Demographics domestic tourist are studied through percentage method.

\subsection{DEMOGRAPHICS OF DOMESTIC TOURISTS}

The demographics of inbound tourist are shown in table 1.Maximum number of Domestic tourist is male $(53.33 \%)$ \& highest portion of domestic tourist is in 26 to 35 years of age (35.11\%) majority of domestic tourist is under graduates $(33.33 \%)$ a largest proportion of domestic tourists is in monthly income of Rs.50, 001-Rs.60, 000 (34.22\%) and most of domestic tourist is married.

Table1.Demographics of Inbound Tourists

\begin{tabular}{|l|l|l|}
\hline \multicolumn{1}{|c|}{ Demographics } & \multicolumn{1}{c|}{ Number } & \multicolumn{1}{c|}{$\%$} \\
\hline Gender & & 53.33 \\
\hline Male & 120 & 46.67 \\
\hline Female & 105 & \\
\hline Age & & 13.33 \\
\hline Below 25 years & 30 & 35.11 \\
\hline $26-35$ years & 79 & \\
\hline
\end{tabular}




\begin{tabular}{|l|l|l|}
\hline $36-45$ years & 71 & 31.56 \\
\hline Above 45 years & 45 & 20.00 \\
\hline Education & & \\
\hline Higher Secondary & 38 & 16.89 \\
\hline Diploma & 48 & 21.33 \\
\hline Under Graduation & 75 & 33.33 \\
\hline Post-Graduation & 64 & 28.45 \\
\hline Monthly Income & & \\
\hline Less than Rs.50,000 & 41 & 18.22 \\
\hline Rs.50,001 - Rs.60,000 & 77 & 34.22 \\
\hline Rs.60,001 - Rs.70,000 & 67 & 29.78 \\
\hline More than Rs.70,000 & 40 & 17.78 \\
\hline Marital Status & & \\
\hline Married & 178 & 79.11 \\
\hline Unmarried & 47 & 20.89 \\
\hline 8.2. & & \\
\hline
\end{tabular}

\subsection{HERITAGE TOURISM IN CHENNAI}

Chennai being developed with the areas of technology and it also acts as a hub of tourism with modern technologies. The heritage tourism in chennai is being greater attractions for more outbound tourist as the architectural style will be the key element to visit and also the heritage been preserved with the new era technologies, without changes in the dynamic restoration methods. In chennai the heritage building where the important public places such as railway stations, universities, courts, banks, gallery and colleges. All these been used by hundreds of people in day to day life. The architectural style and the usages are merged as per public amenities needed and the government Pubic Work Department also does the conservation work to restore the heritage as per their schedules.

Chennai the capital city has several unique buildings which have its own cultural and heritage value. The historic and architectural importance of chennai hidden by the ocean of hoardings and the chaos of the overflowing streets, the fascinating past of Madras lives in its many buildings, public and private. The guidance from the government towards heritage monuments will be helpful for the tourist to fulfill the enjoyment and also helps to explore architectural beauty of the city to a great extent.

\section{CONCLUSION}

As this research it is known that Chennai attracts more tourist, with worth of it own structure and publicity at the world level, tourism in Chennai is all about the travel and transportation in its operation is vital part. The growth of chennai tourism and the search for new sites have resulted in a new market for nature reserves, were as the government new plans for the development of the city, and on the other side effects the environment through exploitation. As the development is also been on the essential part should be done with the conservative measures is advocated in future. 


\section{REFERENCE}

[1] R. Panneerselvam, Dr. A. ApsaraSaleth Mary (2019) HERITAGE TOURISM IN TAMILNADU: POTENTIAL AND CHALLENGES, Journal of Emerging Technologies and Innovative Research (JETIR),(ISSN-2349-5162) Volume 6, Issue 1 www.jetir.org.

[2] M. Chitra, A. Arun (2016) TOURIST PREFERENCE ON CHENNAI TOURISM, International Journal of Advanced Research (IJARMSS), (ISSN: 2278-6236), Vol. 5 No. 7, www.garph.co.uk IJARMSS.

[3] Dr. E. Iniyan (2015), TOURISM IN TAMILNADU: ROLE OF CULTURAL/HERITAGE SITES IN TOURIST SATISFACTION AND TOURISM DEVELOPMENT, International Journal of Humanities \& Social Science Studies (IJHSSS), (ISSN: 2349-6959) Volume-I, IssueVI, May 2015, Page No. 47-54, http://www.ijhsss.com.Silberberg, T., CULTURAL TOURISM AND BUSSINESS OPPORTUNITIES FOR MUSEUMS AND HERITAGE SITES, Tourism Management, 1995, pp. 361-365.

[4] Dr.V.Jeyaraj, MUSEOLOGY HERITAGEMANAGEMENT, Director of Museums, Chennai (2005), P.214.

[5] Neeraj Sharma, DEVELOPMENT OF TOURISM, Sampark Prakashan,Allahabad (2016), P.121.

[6] S.Muthiah, MADRAS IT'S PAST AND PRESENT, East-West press Private Limited (1995), P.213. 